\title{
Percutaneous Transhepatic Cholangiography
}

\author{
S. G. ELKINGTON,* M.B., M.R.C.P. ; D. C. BERNSTEIN, † B.M., F.F.R.
}

Brit. med. F., 1964, 2, 733-735

Chemical and histological studies are often unable to differentiate chronic extrahepatic obstructive jaundice (due to calculi, neoplasia, or stricture) from chronic intrahepatic obstructive jaundice (caused by primary biliary cirrhosis or by drugs, notably anabolic steroids and phenothiazine derivatives). Oral and intravenous cholangiography are also ineffective when the serum bilirubin is greater than 2-3 mg. $/ 100 \mathrm{ml}$. In such circumstances percutaneous transhepatic cholangiography may be useful, since this method can demonstrate the dilated intrahepatic biliary system which develops in chronic extrahepatic obstruction; while a negative result may remove the need for laparotomy in a patient with hepatocellular disease. Since Atkinson et al. (1960) remarked on the revival of interest in this investigation numerous authors (Santos et al., 1960 ; Kaplan, et al., 1961 ; Shaldon et al., 1962 ; Arner et al., 1962 ; Flemma et al., 1963) have agreed on its value. Only one of these reports has come from this country, and the British Medical fournal (1964) suggests that percutaneous transhepatic cholangiography has still to gain general acceptance in Great Britain. This report of a small series with a case history and a brief survey of recent studies may be of interest.

\section{Material and Method}

Eight patients were examined, two of them twice, using the technique described by Kaplan et al. (1961). In this method a needle $15 \mathrm{~cm}$. in length and $1 \mathrm{~mm}$. in bore is inserted under local analgesia through a point immediately below the right costal margin and $3-4 \mathrm{~cm}$. from the midline. The needle is advanced for $12 \mathrm{~cm}$. into the liver at an angle of 45 degrees to the horizontal and inclined to the patient's right. The patient

* Lately Medical Registrar, St. Thomas' Hospital, London.

† Lately Assistant Radiologist, $X$-ray Department, St. Thomas's Hospital, London. is instructed to hold his breath as the needle is moved to avoid injury to the liver capsule. The needle is then attached to a $100-\mathrm{ml}$. syringe by means of a $25-\mathrm{cm}$. length of translucent Portex tubing fitted with adaptors. Suction is applied and the needle is slowly withdrawn. Entry into a distended duct is shown by the aspiration of bile which may vary in colour from golden to "white" (mucus). The tubing is disconnected and washed out with saline if blood enters it. When bile is obtained, as large a volume as possible is drawn off in order to decompress the biliary system and so reduce the risk of biliary peritonitis. When no more bile can be aspirated $20-30 \mathrm{ml}$. of $75 \%$ Diaginol (sodium acetrizoate) is injected into the biliary system as contrast medium. The needle may then be withdrawn; or be retained in position until satisfactory radiographs have been obtained, and used to aspirate the contents of the intrahepatic bile-ducts once more. If a duct is not found the needle is inserted again in a slightly different direction. Not more than four attempts should be made.

Some variants of this method have been described. The lateral approach to the liver in the mid-axillary line is useful in patients with much scar tissue in the anterior abdominal wall and was used on two occasions in this series. To avoid the disadvantages of keeping a needle in the liver for several minutes, some workers (Shaldon et al., 1962 ; Arner et al., 1962) introduce a fine polyethylene catheter over the needle, which is then withdrawn, leaving the catheter in situ. This technique was not employed in the present series.

To reduce the risk of haemorrhage the platelet count should exceed $100,000 / \mathrm{c} . \mathrm{mm}$. and the prothrombin time should be normal. If haemorrhage or biliary peritonitis occurs early surgical intervention is essential: all patients were therefore investigated in the morning and fasted for the rest of the day. Unless facilities for laparotomy are readily available the investigation should not be performed.

The results are presented in Table I.

TABLE I

\begin{tabular}{|c|c|c|c|c|c|c|c|}
\hline $\begin{array}{l}\text { Case } \\
\text { No. }\end{array}$ & Age & Sex & $\begin{array}{c}\text { Duration of } \\
\text { Jaundice } \\
\text { (months) }\end{array}$ & $\begin{array}{l}\text { Cholangiographic } \\
\text { Findings }\end{array}$ & $\begin{array}{c}\text { Cholangiographic } \\
\text { Diagnosis }\end{array}$ & $\begin{array}{l}\text { Operative } \\
\text { Findings }\end{array}$ & Remarks \\
\hline 1 & 37 & $\mathrm{~F}$ & 23 & $\begin{array}{l}\text { Dilatation of biliary sys- } \\
\text { tem above stricture of } \\
\text { CBD (Fig. 2) }\end{array}$ & Stricture of CBD & Stricture of CBD & Successful operative repair \\
\hline 2 & 55 & M & 4 & & None & $\begin{array}{l}\text { Multiple minute calculi. } \\
\text { Dilated GB and CBD }\end{array}$ & $\begin{array}{l}\text { No operative cholangiogram performed : size of } \\
\text { intrahepatic ducts not known }\end{array}$ \\
\hline 3 & 38 & $\mathrm{~F}\{$ & $\begin{array}{l}\text { Pre-operative } \\
27 \\
\text { Post-operative } \\
28\end{array}$ & $\begin{array}{l}\text { Dilatation of intrahepa- } \\
\text { tic ducts. CBD normal } \\
\text { Dilatation unaltered }\end{array}$ & 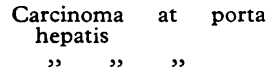 & $\begin{array}{c}\text { Carcinoma at } \\
\text { hepatis }\end{array}$ & $\begin{array}{l}\text { Pain for } 20 \text { minutes after withdrawal of needle. } \\
\text { Operative relief of obstruction attempted } \\
\text { Death from hepatic failure } 3 \text { months after operation }\end{array}$ \\
\hline 4 & 72 & $\mathbf{M}$ & 2 & $\begin{array}{l}\text { Bile aspirated but Diagi- } \\
\text { nol entered peritoneal } \\
\text { cavity }\end{array}$ & $\begin{array}{l}\text { Intrahepatic ducts dila- } \\
\text { ted but not visualized }\end{array}$ & No operation performed & $\begin{array}{l}\text { Ankylosing spondylitis and gross kyphoscoliosis. } \\
\text { Injection caused slight transient pain. Died } 6 \\
\text { months later. PM showed carcinoma of } \\
\text { pancreas }\end{array}$ \\
\hline 5 & 53 & M & 7 & Negative & None & $\begin{array}{l}\text { Biliary peritonitis. } \\
\text { Carcinoma of pancreas }\end{array}$ & $\begin{array}{l}\text { Failure to aspirate bile due to use of smaller needle. } \\
\text { Successful cholecystenterostomy with decom- }- \\
\text { pression of biliary system. Died } 6 \text { months later } \\
\text { from extension of neoplasm }\end{array}$ \\
\hline 6 & 70 & $\mathbf{F}$ & 4 & Negative & None & No operation performed & $\begin{array}{l}\text { Presumptive diagnosis: intermittent calculous } \\
\text { obstruction of CBD }\end{array}$ \\
\hline 7 & 44 & $\mathbf{M}$ & $\begin{array}{c}\text { Pre-operative } \\
2\end{array}$ & $\begin{array}{l}\text { Dilatation of ducts in } \\
\text { right lobe: filling de- } \\
\text { fect in CHD }\end{array}$ & $\begin{array}{l}\text { Carcinoma at porta } \\
\text { hepatis }\end{array}$ & $\begin{array}{l}\text { Carcinoma at porta } \\
\text { hepatis }\end{array}$ & T-tube inserted to drain right lobe \\
\hline & & & Post-operative & Negative & $\begin{array}{l}\text { Right intrahepatic ducts } \\
\text { not dilated }\end{array}$ & - & Returned to work with T-tube in situ \\
\hline 8 & 50 & $\mathrm{~F}$ & 1 & $\begin{array}{l}\text { Multiple filling defects in } \\
\text { GB }\end{array}$ & Calculi in GB & Calculi in GB. Cirrhosis & $\begin{array}{l}\text { Needle entered GB through bare area. Aetiology } \\
\text { of cirrhosis unknown. Portal hypertension and } \\
\text { oesophageal varices present }\end{array}$ \\
\hline
\end{tabular}

$\mathrm{CBD}=$ Common bile-duct. $\quad \mathrm{CHD}=$ Common hepatic duct. $\mathrm{GB}=$ Gall-bladder. $\mathrm{PM}=$ Post-mortem 


\section{Illustrative Case}

A housewife (Case 1) was first seen at St. Thomas's Hospital in September 1959 when aged 34 . She complained of epigastric pain of five years' duration and recent loss of $40 \mathrm{lb}$. (18 kg.) in weight. A diagnosis of peptic ulcer was made, but a barium-meal examination revealed nothing abnormal. She was treated with alkalis, while to allay anxiety chlorpromazine $25 \mathrm{mg}$. was also given twice daily for two weeks. One month after withdrawal of this drug she developed a febrile illness with anorexia, vomiting, pruritus, and pale stools. Examination revealed a thin jaundiced woman with a tender liver of normal size. Liver-function tests showed the pattern of obstruction (serum bilirubin $7.8 \mathrm{mg} . / 100 \mathrm{ml}$., thymol turbidity 3 units, serum alkaline phosphatase 35 King-Armstrong units). From the mode of onset infective hepatitis was suspected, but when no improvement had occurred within four weeks she was admitted for further examination. No fresh physical signs were present, and biochemical investigation still indicated biliary obstruction rather than hepatocellular disease. Histology of a needle-biopsy specimen also suggested extrahepatic obstruction. Accordingly laparotomy was performed on 8 December 1959: a thick-walled gall-bladder containing mixed stones was found. The common bile-duct was normal and an operative cholangiogram showed that there was no obstruction in the biliary system. Cholecystectomy was carried out. Her post-operative recovery was satisfactory and a T-tube cholangiogram (Fig. 1) was normal. Despite this the jaundice was slow to clear and when she was discharged in January 1960 the diagnosis remained uncertain.

During the next five months she slowly gained weight but did not enjoy good health. The liver-function tests improved but were still abnormal in April 1960 (serum bilirubin $1 \mathrm{mg} . / 100 \mathrm{ml}$., thymol turbidity 2 units, serum alkaline phosphatase 36 King-Armstrong units). In June 1960 she relapsed, with recurrence of malaise and jaundice. In October prednisone $5 \mathrm{mg}$. twice daily was given for four weeks, resulting in a fall in the serum bilirubin. After deterioration in December there was some improvement in the early months of 1961. However, out-patient study consistently suggested biliary obstruction and she was readmitted in June 1961 for further investigation.

As before, she was thin and faintly jaundiced. There was a spider naevus on the forehead and the liver was hard, enlarged, and irregular. The spleen tip was just palpable. A needle-biopsy specimen of the liver now showed early cirrhotic change consequent on chronic biliary obstruction.

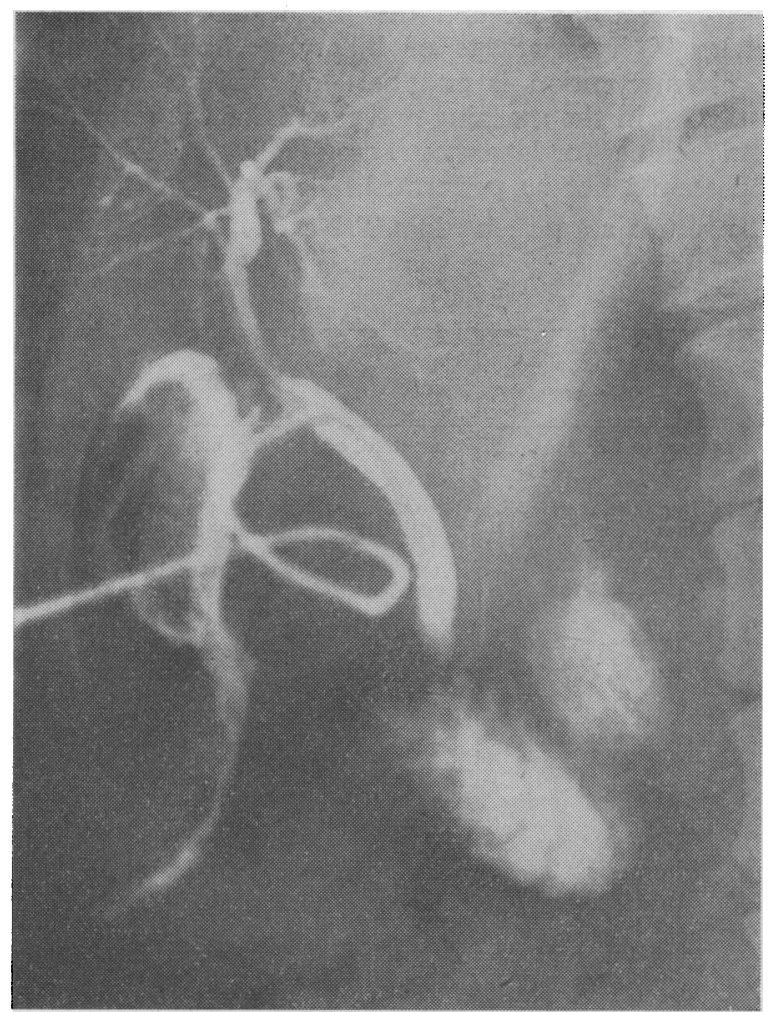

FIG. 1.-Case 1. December 1959 ; cholangiogram normal.
Other investigations resulted as follows: haemoglobin $61 \%$ (9 g. $/ 100 \mathrm{ml}$.) ; mean corpuscular haemoglobin concentration $27 \%$; total white-cell count $7,000 /$ c.mm. ; E.S.R. $40 \mathrm{~mm}$. in one hour (Westergren); no L.E. cells seen. Prothrombin time normal. Serum proteins: albumin $4.6 \mathrm{mg}$., globulin $1.9 \mathrm{mg} . / 100 \mathrm{ml}$. Serum cholesterol $230 \mathrm{mg} . / 100 \mathrm{ml}$; ; serum bilirubin $1.4 \mathrm{mg} . / 100 \mathrm{ml}$.; serum alkaline phosphatase 64 King-Armstrong units; thymol turbidity 1 unit; żinc sulphate turbidity 4 units; serum glutamic oxalacetic transaminase 68 units.

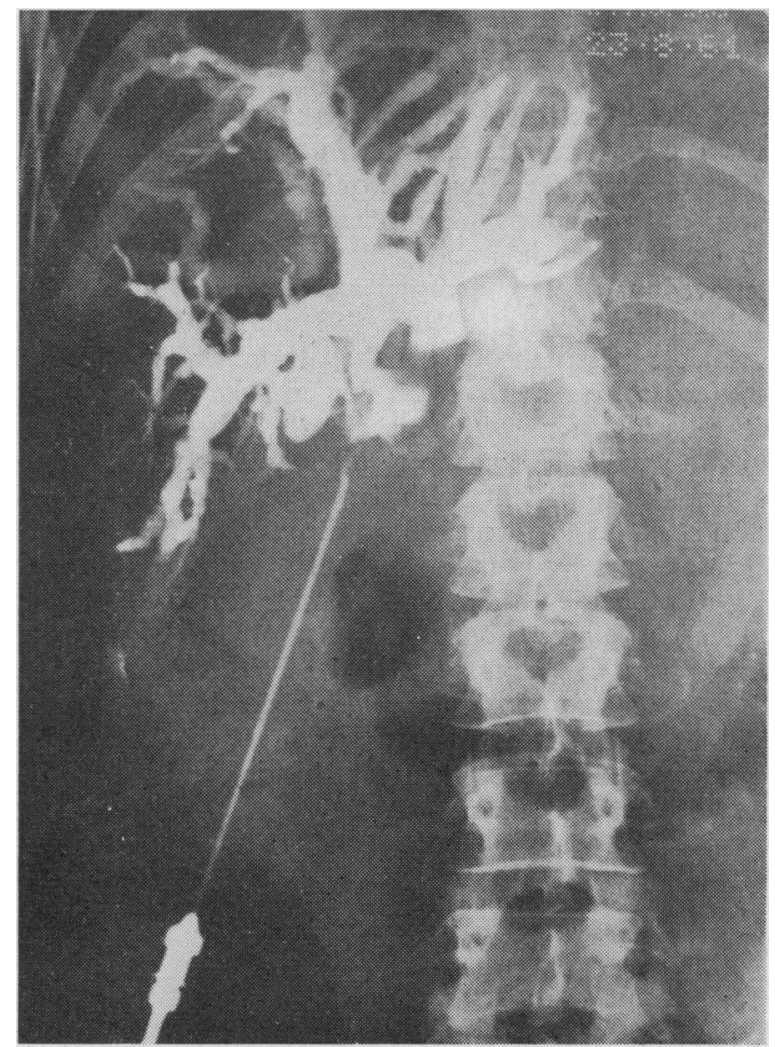

FIG. 2.-Case 1. August 1961 ; cholangiogram showing evidence of chronic biliary obstruction and stricture of the common bile-duct.

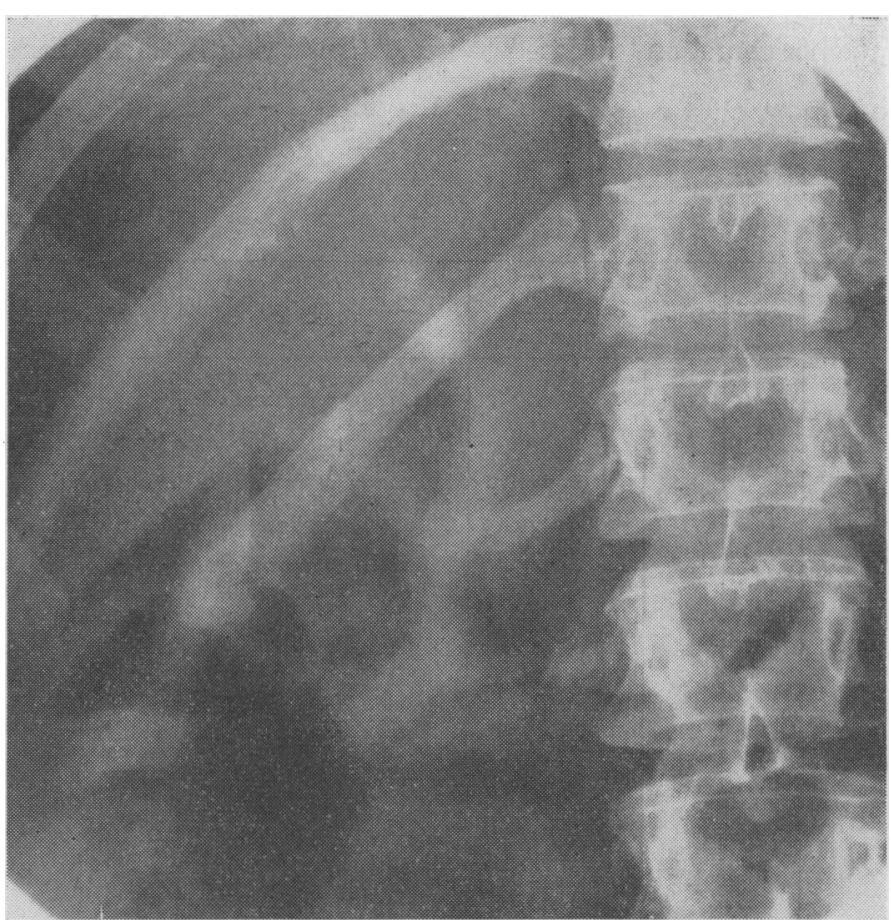

FIG. 3.-Case 1. June 1963 ; intrahepatic bile-ducts almost normal in size, but the common bile-duct slightly dilated. 
An intravenous cholangiogram did not outline any bile-ducts. Partial obstruction of the biliary system appeared to be the most rrobable diagnosis, but without evidence of the nature and site of the lesion a second laparotomy was not thought justifiable. It was at this point that percutaneous transhepatic cholangiography was performed, providing convincing evidence of chronic biliary obstruction and demonstrating a stricture of the common bile-duct (Fig. 2). At operation on 5 September 1961 (Mr. Lockhart Mummery) a stricture of the common bile-duct was dilated. A polyethylene tube was passed through it and left to drain to the exterior for two weeks.

Post-operative improvement was rapid, with early loss of pruritus and jaundice. In the three years since that time she has remained in excellent health, gaining $30 \mathrm{lb}$. $(13.6 \mathrm{~kg}$.) in weight. The liver is no longer enlarged, but the serum alkaline phosphatase is still slightly raised (31 King-Armstrong units). Intravenous cholangiography in June 1963 showed that the intrahepatic bile-ducts were almost normal in size but that there was still slight dilatation of the common bile-duct (Fig. 3).

\section{Discussion}

This series, although small, illustrates several points concerning percutaneous transhepatic cholangiography. First, it is a simple investigation which may give most valuable information, clarifying an obscure clinical situation, permitting surgery on the biliary passages to be planned in advance, and obviating the need for surgery in those cases of hepatocellular disease most likely to be harmed by it.

Secondly, as Case 5 shows, it carries an appreciable risk of haemorrhage and of biliary peritonitis, although this should be weighed against the risk of the alternative method of diagnosis -namely, surgical exploration of the biliary system. Atkinson et al. (1960), in a study of 21 cases, together with a survey of the world literature (excluding, however, the results obtained by Richieri (1957), which are incompletely reported), found that among 277 patients death had occurred in two instances and biliary peritonitis in nine, a combined incidence of $4 \%$. Numerous reports have appeared since that time: Table II, though not a complete review of the literature, summarizes the results of 11 subsequent studies.

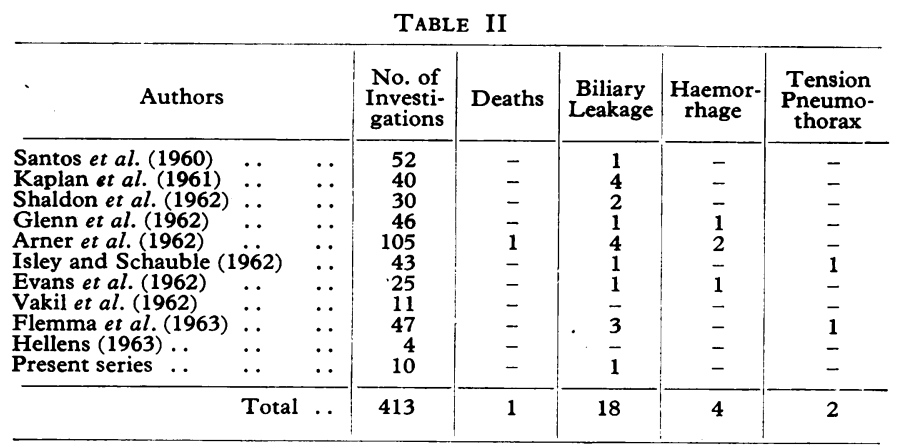

It will be seen that death or major complication occurred in 25 patients out of a total of 413 investigations, an incidence of $6 \%$. It is noteworthy that in the series described by Glenn et al. (1962), both patients who developed a complication were investigated under general anaesthesia; and that the only death occurred post-operatively, laparotomy having been delayed for a week as infection of the biliary system was suspected. There are several reports that when, at operation for biliary peritonitis, a free flow of bile was established to the gut, the escape from the site of puncture ceased: this agrees with our experience in Case 5.

There is thus much evidence to show that the risk of complication following this investigation is in the region of $4-6 \%$. A comparison with figures for mortality after exploration of the biliary system, quoted by Evans et al. (1962) from United States sources as being 3-10\% even in the absence of hepatocellular disease, suggests that percutaneous transhepatic cholangiography could profitably be performed more often.

Thirdly, a number of negative results occur, and there may be difficulty in deciding whether this indicates failure to locate dilated ducts, or their absence. Interpretation has depended upon the experience and confidence of the individual worker (Shaldon et al., 1962) but the recent introduction of television fluoroscopy (Glenn et al., 1962 ; Arner et al., 1962) may prove a considerable advance, since this technique can demonstrate ducts of normal size in $50 \%$ of patients with an undilated biliary system (Arner et al., 1962). If this proportion can be increased it will become possible to diagnose a normal biliary system by percutaneous transhepatic cholangiography as readily as a distended system can be diagnosed at present.

\section{Summary}

Details are given of eight patients investigated by percutaneous transhepatic cholangiography, together with an illustrative case history.

One patient developed biliary peritonitis. A brief review of 413 reported investigations shows that complication occurs in $6 \%$ while the mortality from surgical exploration of the biliary system is $3-10 \%$.

The value of this investigation in selected cases of chronic obstructive jaundice should be more generally appreciated.

We are indebted to the physicians of St. Thomas's Hospital for allowing us to study patients under their care, and in particular to Dr. J. B. Harman for permission to report Case 1.

\section{REFERENCES}

Arner, O., Hagberg, S., and Seldinger, S. I. (1962). Surgery, 52, 561. Atkinson, M., Happey, M. G., and Smiddy, F. G. (1960). Gut, 1, 357. Brit. med. f., 1964, 1, 196.

Evans, J. A., Glenn, F., Thorbjarnarson, B., and Mu,ahed, Z. (1962) Radiology, 78, 362 .

Flemma, R. J., Schauble, J. F., Gardner, C. E., jun., Anlyan, W. G., and Capp, M. P. (1963). Surg. Gynec. Obstet., $116,559$.

Glenn, F., Evans, J. A., Mujahed, Z., and Thorbjarnarson, B. (1962). Ann. Surg., 156, 451.

Hellens, A. von (1963). Ann. Chir. Gynaec. Fenn., 52, Suppl. No. 121,

Isley, J. K., and Schauble, J. F. (1962). Amer. F. Roentgenol., 88, 772. Kaplan, A. A., Traitz, J. J., Mitchel, S. D., and Block, A. L. (1961). Ann. intern. Med., 54, 856.

Richieri, A. (1957). Pren. méd. argent., 44, 2865.

Santos, M., Figueroa, L., and López, O. (1960). Surgery, 48, 295.

Shaldon, S., Barber, Kathleen M., and Young, W. B. (1962). Gastroenterology, 42, 371 .

Vakil, B. J., Tulpule, T. H., Shah, S. J., and Desai, M. G. (1962). F. Indian med. Ass., 39, 281. 